\title{
Przygotowanie do startu w dorosłość - młodzież w okresie tranzycji z edukacji na rynek pracy
}

\author{
Preparing for a start into adulthood - young people in \\ transition from education to the labor market
}

Streszczenie. Okres dorastania stanowi czas nie tylko intensywnych przemian dokonujących się w niemalże wszystkich aspektach funkcjonowania podmiotu, ale także wiąże się z licznymi zadaniami, którym zobowiązana jest sprostać jednostka chcąc stać się osobą dorosłą. Jedno z nich odnosi się do przygotowania młodego człowieka do kariery zawodowej i partycypowania w przestrzeni rynku pracy. Przyglądanie się działaniom młodzieży związanym z rozwojem zawodowym, okazuje się niezwykle interesujące poznawczo ze względu na fakt, że w perspektywie niedalekiej przyszłości to właśnie oni staną się kreatorami rynku pracy. Niniejsza grupa uznawana jest bowiem za podmiot przemian społecznych, na podstawie zachowań której prognozuje się różnorodne tendencje i zjawiska społeczno-kulturowe. Warto zatem poddać bliższemu oglądowi kwestię przygotowania młodych ludzi do startu w dorosłość oraz zastanowić się, jakie czynniki je warunkują.

Wyniki badań własnych ukazują zróżnicowany obraz młodzieży charakteryzującej się niejednolitym stopniem przygotowania do startu w dorosłość. Uzyskany materiał empiryczny wskazuje na dominującą tendencję respondentów do dookreślenia siebie poprzez pryzmat indywidualistycznych właściwości, wyróżniających ich spośród innych ludzi. Podejmując refleksję nad sobą w przyszłości definiują siebie przez pryzmat roli zawodowej, jaką zamierzają pełnić. Fakt, że ponad połowa badanych w przyszłości chciałaby wykonywać wybrany zawód, świadczy o tym, iż sfera rozwoju zawodowego nie pozostaje dla nich obojętna.

Słowa kluczowe: młodzież; tranzycja z edukacji na rynek pracy; start w dorosłość; zadania okresu dorastania; rynek pracy

Summary. Adulthood constitutes a time of not only intensive transitions taking place in almost all the aspects of the subject's functioning; it also involves a number of tasks that the individual is obliged to face in order to become an adult. One of them refers to the preparation of a young person for a career and participation in the labor market area. Looking at the 
actions of youth related to professional development turns out to be extremely interesting in cognitive terms because of the fact that in the near future they will become the creators of the labor market. This group is considered as the subject of social change, and on the basis of their behavior, various socio-cultural tendencies and phenomena are predicted. The issue of preparing young people to take on adulthood and to consider what factors condition it is therefore worth looking at.

The results of our own research show a diverse picture of young people characterized by an uneven degree of preparation for 'taking off' into adulthood. The obtained empirical material indicates that the dominant tendency of respondents is to define themselves through the prism of individualistic properties that distinguish them from other people. When they reflect on themselves in the future, they define themselves through the perspective of the professional role they intend to play. The fact that more than a half of the respondents would like to pursue their chosen profession in the future testifies to the fact that the sphere of professional development is not indifferent to them.

Key words: youth; transition from education to the labor market; adulthood; tasks of adolescence; labor market

\section{Wprowadzenie}

Kondycja współczesnego rynku pracy w znacznym stopniu determinowana jest przez konglomerat przemian globalnych oraz szereg wzajemnie oddziałujących na siebie czynników politycznych, ekonomicznych, technologicznych, społecznych (Szaban 2013, s. 34-35). Stanowi on przestrzeń, do partycypowania w której w mniejszym lub większym stopniu zostaje zobligowany każdy człowiek podejmujący się aktywności zawodowej. Można określić go mianem elastycznego ze względu na jego niestabilną naturę, która nie pozostaje obojętna dla jednostki zobowiązanej do nieustannego dopasowywania się do okoliczności, co niejednokrotnie wiąże się ze zmianą miejsca zatrudnienia czy podnoszenia kwalifikacji. Postępujący proces technologiczno-naukowy umożliwiający szybki transfer informacji, wzrastająca konkurencja gospodarcza, zmiany w sferze pracy i zatrudnienia, stawiają podmiot nie tylko w sytuacji zachowania ciągłej czujności, ale także wymagają od niego szybkiej adaptacji do zaistniałych warunków. Okazuje się ona możliwa dzięki urzeczywistnianiu idei permanentnego uczenia się, nieustannego zdobywania nowej wiedzy, poszerzenia posiadanych umiejętności i wszechstronnego rozwoju osobowości. Wśród najistotniejszych cech charakterystycznych rynku pracy warto wskazać: globalizacje gospodarki, rozwój i upowszechnianie technologii teleinformatycznych, wzrost 
znaczenia sektora usług, zmieniający się system wartości, wzrost poziomu wykształcenia, wzrost samozatrudnienia, coraz większe zapotrzebowanie na tzw. kwalifikacje miękkie, zmiana relacji czasu wolnego do czasu pracy, zmniejszenie znaczenia pracy etatowej, rozwój pracy zadaniowej i elastycznych form zatrudnienia, duża skala emigracji powodująca brak określonych grup pracowników, coraz bardziej różnicujące ich wynagrodzenie, szybka dezaktualizacja wiedzy, nadprodukcja lub niedobór w określonych zawodach i specjalnościach oraz coraz większe zapotrzebowanie na absolwentów szkół zawodowych (Rosalska, Wawrzonek 2012, s. 123).

Istotnym czynnikiem integrującym i dynamizującym życie współczesnych społeczeństw okazuje się informacja. Dlatego też, aby zapewnić rozwój gospodarek opartych na wiedzy, znaczący namysł podejmuje się nad kwestią szeroko pojętej edukacji, która stanowi ważki element determinujący los przedstawicieli różnych grup społecznych. Posiadane przez absolwentów kończących poszczególne typy szkół kompetencje i kwalifikacje odgrywają doniosłą rolę w procesie oceny ich przygotowania do realizowania obranej ścieżki kariery, a w konsekwencji w dookreślaniu zajmowanej przez nich pozycji na rynku pracy. Wyniki analiz Jacka Liwińskiego i jego zespołu badawczego dowodzą, że edukacja warunkuje nie tylko zawodowe możliwości podmiotu, ale przynosi korzyści dla jego pozazawodowych aktywności. Okazuje się bowiem, iż osoby lepiej wykształcone są zdrowsze, rzadziej łamią prawo oraz szybciej dostosowują się do zmian społecznych (Liwiński, Socha, Sztanderska 2000, s. 27-85). Ze względu na istotną rolę społeczną kształcenia, dokonuje się opracowywania licznych modeli teoretycznych dotyczących edukacji i jej powiązań z rynkiem pracy. Warto w tym miejscu przywołać teorie kapitału ludzkiego (postrzegającą szkolnictwo przez pryzmat inwestycji w rozwój poszczególnych jednostek, których sukces przyczyni się do podniesienia znaczenia całego społeczeństwa), merytokracji (zakładającej równe szanse wszystkich ludzi na osiągnięcie upragnionej pozycji na rynku pracy, określanej przez ich umiejętności i predyspozycje) czy chociażby kredencjalizmu (przypisującego edukacji rolę kreatora różnic społecznych).

\section{Młodzież w okresie podwójnej tranzycji: z edukacji na rynek pracy oraz z okresu dorastania do dorosłości - rozważania ogólne}

W sytuacji istnienia ważnych powiązań pomiędzy edukacją a rynkiem pracy, należy przyjrzeć się zjawisku związanemu z przemieszczaniem się mię- 
dzy tymi dwoma obszarami. Pojęcie tranzycji wywodzi się z angielskiego słowa transition odnoszącego się do procesu przechodzenia przez jednostkę z jednej płaszczyzny aktywności do drugiej. Propozycję jego rozpatrywania w różnych perspektywach przedstawił Jean Guichard, przedkładając cztery zasadnicze sposoby rozumienia tranzycji: jako zmiany spowodowanej losowymi zdarzeniami, przejścia jednostki z jednego kontekstu aktywności do innego, związanej także z przekształceniem towarzyszących mu okoliczności, procesu psychospołecznego, czy też wspomnianego przejścia z jednego etapu do drugiego (Guichard 2007). W takim ujęciu stanowi ona fenomen znamionujący się nie tylko stosunkową złożonością i dynamiką, ale również niejako wpisany w tok egzystencji podmiotu, wprowadzając w niej określone przeobrażenia dotyczące stylu życia, decyzji, sposobu postrzegania świata lub własnej osoby. Violetta Drabik-Podgórna jego zasięgiem obejmuje „różne zjawiska związane $\mathrm{z}$ «przerwami» $\mathrm{i}$ «przejściami» w zawodowym i osobistym życiu jednostek" (Drabik-Podgórna 2010, s. 93). W aspekcie rynku pracy, tranzycję należy zatem ujmować w kategorii okresu, w którym kończy ona wybrany etap edukacji i rozpoczyna swoją aktywność w obszarze zawodowym. Warto zaznaczyć także, iż odnosi się ona do młodych ludzi, którzy kończą naukę na poziomie szkolnictwa średniego lub wyższego, jak i również doświadczających innych istotnych zmian w życiu, takich jak opuszczanie domu rodzinnego lub stawanie się osobą dorosłą (Bowman, Borlagdan, Bond 2015, s. 6). Analiza terminu tranzycji w kontekście rytuałów przejścia pozwala na przyglądanie się mu w odniesieniu do różnorodnych przemian w toku biografii jednostki.

Prowadzenie eksploracji dotyczących tego aspektu ludzkiego życia okazuje się niezwykle istotne zarówno z perspektywy konkretnych wskazówek dla systemu szkolnictwa tudzież rynku pracy, ale także rozpoznania przygotowania młodzieży do startu w dorosłość. Zdobycie wykształcenia oraz znalezienie odpowiedniego zatrudnienia znacząco oddziałuje na jakość egzystencji podmiotu, najczęściej w długoterminowej perspektywie (Tilbury, Buys, Creed 2009, s. 476-477). Wszelkie trudności w osiąganiu stabilizacji finansowej oraz godnych warunków zatrudnienia, niosą za sobą niekorzystne konsekwencje dla realizacji zadań charakterystycznych dla dorosłości, takich jak kupno własnego mieszkania czy założenie rodziny, jak i również negatywnie oddziałują na ocenę własnej osoby i wiarę w swoje możliwości (tamże, s. 476-490).

Pomyślność przejścia z edukacji na rynek pracy warunkowana jest przez szereg czynników, wśród których należy wskazać determinanty: ekonomiczne (dotyczące aktualnej sytuacji gospodarczej kraju), indywidualne 
(odnoszące się do jednostkowych właściwości podmiotu, takich jak płeć czy aspiracje, motywacje), demograficzne, psychologiczne, polityczne, koniunkturalne oraz związane ze zgromadzonym kapitałem edukacyjnym jednostki i przemianami mającymi miejsce w szkolnictwie (Piróg 2013, s. 133-134). Nie należy także zapominać o kapitale kariery, definiowanym przez Augustyna Bańkę jako „zakumulowane kompetencje, które jednostka uzyskuje w toku edukacji, pracy, doświadczenia życiowego, doświadczenia społecznego i kulturowego" (Bańka 2006, s. 80). W takim rozumieniu, można uznać go za osobliwą właściwość każdego człowieka, będącą rezultatem oddziaływania wyżej wymienionych wskaźników oraz innych paramentów wiążących się z jego statusem socjoekonomicznym. Elżbieta Turska w swoich rozważaniach wyodrębnia kategorię „startowego kapitału kariery”, w obszar którego zalicza następujące rodzaje kapitałów: edukacyjny, doświadczenia zawodowego, przedsiębiorczości i językowy (Turska 2014, s. 48-74). Tranzycja stanowi zatem złożony proces, którego wynik jest wypadkową licznych zmiennych zależnych od wewnętrznych właściwości podmiotu i zewnętrznych wobec niego determinantów.

\section{Zadania okresu dorastania a przygotowanie młodzieży do „startu” w dorosłość}

Rozważając problematykę przechodzenia młodzieży z edukacji na rynek pracy oraz z dorastania do dorosłości, warto poddać bliższemu oglądowi ogólne prawidłowości związane z tymi procesami. Młodzież określana jest jako „kategoria wiekowa jednostek będących w stadium przejściowym między dzieciństwem a dorosłością, zmierzających w toku socjalizacji i rozwoju do osiągnięcia pełnej dojrzałości” (Pilch 2003). W kontekście takiego jej ujmowania, należy podjąć namysł nad zadaniami, którym zobowiązany jest sprostać adolescent, chcąc być uznany za osobę dorosłą. Robert Havighurst zwraca uwagę na osiem takich powinności, w poczet których zalicza: akceptację własnego wyglądu fizycznego i rozpoznanie możliwości własnego organizmu, opanowanie ról społecznych przypisanych do określonej płci, opanowanie umiejętności nawiązywania dojrzałych relacji interpersonalnych, przygotowanie do pełnienia roli małżonka i założenia rodziny, opanowanie zdolności realizacji kariery zawodowej, ukształtowanie własnego systemu wartości oraz osiągnięcie zachowania zgodnego z duchem społecznej dojrzałości i odpowiedzialności (Havighurst 1981). Z kolei Barbara Varenhorst wśród celów rozwojowych, do realizacji których dąży jednostka w okresie ad- 
olescencji, wskazuje: osiągnięcie fizycznej dojrzałości seksualnej oraz własnej indywidualności, podjęcie zobowiązań społecznych, przyjmowanie nowych ról, uzyskanie autonomii, wyrastanie z egocentryzmu i reorganizację systemu wartości (Varenhorst 1981). Badaczka rozpatruje dorastanie z perspektywy procesu ukierunkowanego na określony rezultat, którego istota polega na osiągnięciu niezależności przez młodego człowieka.

W tym miejscu godzi się przywołać dokonania Janusza Reykowskiego, który analizując przebieg dojrzewania społecznego, akcentował konieczność uniezależnienia się nastolatków od wpływów rodziców (Reykowski 1986, s. 389-416). Istotna z perspektywy rozpatrywanej problematyki jest także psychospołeczna koncepcja rozwoju Erika H. Eriksona, ujmująca zmiany zachodzące w cyklu życia z perspektywy dynamicznej relacji opozycyjnych postaw i umiejętności osiąganych w kolejnych etapach egzystencji (Erikson 2004), nie pozostających bez znaczenia dla sfery życia zawodowego. Ponadto intensywny rozwój procesów poznawczych mających miejsce w okresie dorastania, przyczynia się do dostrzegania przez podmiot pewnych zależności przyczynowo-skutkowych, stanowiących podstawę umiejętności przewidywania konsekwencji własnych decyzji (Gerrig, Zimbardo 2006, s. 317-320). Znaczące badania z tego zakresu prowadził Jean Piaget, który dowiódł, że w okresie dojrzewania jednostka nabywa zdolność dokonywania operacji formalnych, stanowiących podstawę myślenia abstrakcyjnego, pozwalającego na kreowanie wizji przyszłych stanów rzeczy (Inhelder, Piaget 1970). Należy także nadmienić, że badania Radosława Drwala dowodzą, iż sama młodzież za jedno z najważniejszych zadań adolescencji obok nawiązywania satysfakcjonujących relacji rówieśniczych, wskazywała na kształtowanie swojej przyszłości, w tym także zawodowej (Drwal 1993, s. 15-47). Warto zauważyć, iż zdobycie umiejętności planowania własnej ścieżki kariery oraz aktywnego partycypowania w przestrzeni rynku pracy, staje się jednymi z zasadniczych powinności okresu dojrzewania. Ponadto, na podstawie etapu rozwoju zawodowego, na jakim znajduje się człowiek - określa się jego dojrzałość zawodową oraz zdolność adaptacji w stosunku do kariery, a zatem stopień radzenia sobie $\mathrm{z}$ aktualnymi zadaniami rozwojowymi.

Współcześnie obserwuje się tendencję do coraz późniejszego podejmowania przez młodych ludzi zobowiązań charakterystycznych dla okresu dorosłości, takich jak zawarcie związku małżeńskiego, urodzenie dziecka, podjęcie stabilnej pracy zarobkowej tudzież kupno mieszkania. Warto mieć na uwadze, iż sytuacja ta uwarunkowana jest nie tylko przez indywidualne decyzje młodzieży, ale także przez szereg czynników wobec niej zewnętrznych, związanych z niepewną sytuacją na rynku pracy, wydłużającym się okresem 
kształcenia czy też specyfiką współczesnej rzeczywistości, obdarzanej mianem „płynnego życia” (Bauman 2007) oraz „migotania znaczeń” (Melosik 2010). Na potrzeby dookreślenia owego zjawiska ukuto termin „wyłaniającej się dorosłości" (ang. emerging adulthood), rozumianej jako okres mający miejsce między 18 a 30 rokiem życia będący nową fazą rozwojową pomiędzy późną adolescencją a wczesną dorosłością (Arnett 2000, 2004). Dokonano bowiem spostrzeżenia, iż w zachodnich, wysoce stechnicyzowanych społeczeństwach można mówić o procesie „stawania się dorosłym”, a zatem „bycia pomiędzy” jednym a drugim stanem (na etapie wychodzenia jednego z obszarów, ale bez osiągnięcia właściwości typowych dla kolejnego). Za cechę atrybutywną tego okresu, uznaje się intensywną labilność ról społecznych charakterystycznych dla osób dorosłych, wyrażającą się w krótkotrwałym ich przyjmowaniu i porzucaniu. Wschodząca dorosłość to czas poszukiwań związanych z tożsamością, światopoglądem oraz systemem wartości, w których pomocna okazuje się intensywna koncentracja na własnej osobie oraz optymistyczne nastawienie do swojej przyszłości (Lipska, Zagórska 2011, s. 15).

Zjawisko względnego wydłużania się okresu dorastania, skutkuje relatywnym wzrostem liczebności młodzieży w strukturze społecznej i tym samym popularyzowaniem zachowań charakterystycznych dla adolescentów. Powszechny we współczesnej kulturze staje się kult młodości, objawiający się między innymi w korzystaniu z młodzieżowych rozrywek oraz oferty konsumpcyjnej adresowanej do tej grupy przez ogół społeczeństwa. Zdaniem Chrisa Gillearda i Paula Higgsa praktyki tego rodzaju stały się tak intensywnie zakorzenione w obyczajowość ludzką, iż okazują się pełnić rolę wyznacznika nowej formy uspołecznienia (Gilleard, Higgs 2005). Z kolei Anna Olejniczuk-Merta analizuje kult młodości w kontekście kategorii stylu życia. Badaczka ta uważa, iż wyraża się on w odchodzeniu od ujmowania młodości jako etapu w życiu jednostki na rzecz przejawiania wysokiego poziomu aktywności, zainteresowań, wartości, opinii typowych dla osób w okresie dojrzewania, niezależnie od wieku jednostki (Olejniczuk-Merta 2012). Przyczyn takiej sytuacji można dopatrywać się w słowach Elżbiety Dubas, która spostrzega, że „współczesne wysokorozwinięte społeczeństwa dają jednostce szanse dłuższego dojrzewania do dorosłości, wprowadzają czas odroczenia dorosłości moratorium i tym samym zezwalają na późniejsze przejmowanie ról człowieka dorosłego" (Dubas 2009, s. 120).

W efekcie obserwuje się powstawanie różnorodnych ujęć teoretycznych opisujących oraz podejmujących próbę wyjaśnienia niniejszego zjawiska. Określeniami używanymi do scharakteryzowania przemian kulturowo- 
-społecznych związanych z fenomenem względnego wydłużania się okresu dorastania, tym samym opóźniania momentu wchodzenia w dorosłość, są „powstrzymująca się dorosłość” (Hendry, Kloep 2010), „moratorium na dorosłość” (Liberska 2007) tudzież „deregulacja cyklu życia” (Trempała 2006). W literaturze anglojęzycznej nie brakuje również terminów wykorzystywanych do określenia młodych ludzi, niechętnych do przyjmowania dojrzałych zobowiązań, takich jak: kidults (Osppe 2016) (korzystający z doświadczeń dorosłości, jednak stroniący od związanych z nią trudów i zobowiązań), adultescent (Tierney 2004) (osoba w średnim wieku, której zainteresowania, sposób ubierania się, odnoszą się do kultury młodzieżowej), individuals locked in a high school of the mind (Epstein 2003) (dorośli legitymujący się mentalnością licealisty), boy-men (Cross 2008) (mężczyzna korzystający z hedonistycznych przyjemności młodości, niechętny do sprostania wymaganiom dorosłości). Natomiast materiał empiryczny zgromadzony przez Jeffreya Arnetta i Jennifer L. Tanner dowodzi, że powszechnie uznawane kryteria osiągnięcia dorosłości ulegają subiektywizacji (Arnett, Tanner 2005), co oznacza, iż poczucie bycia dorosłym nabiera indywidualnego wycieniowania.

O trudnościach młodzieży ze sprostaniem zobowiązaniom zawodowym świadczą pojawiające się koncepcje, obrazujące ich stosunek do własnej kariery. Określeniem pokolenia NEET (ang. Neither in Employment nor in Education and Training) obejmuje się grupę młodych ludzi, którzy „nie uczą się, nie dokształcają i nie uczestniczą w żadnych formach szkoleń" (Balcerowicz-Szkutnik, Wąsowicz 2017, s. 8). Stanowią ją zatem osoby, które w żaden sposób nie podnoszą swoich kwalifikacji ani kompetencji zwiększających ich szanse na uzyskanie zatrudnienia. Rezygnują z realizowania praktyk zawodowych oraz uczestnictwa w różnorodnych formach szkolenia oraz doskonalenia zawodowego. Kolejnym interesującym poznawczo zjawiskiem jest nowa kategoria społeczna - prekariusze (termin powstał z połączenia dwóch słów ang. precarious - niepewny i proletariat), dostrzeżona przez Guya Standinga. Za czynnik towarzyszący jej poswataniu uznaje się masowe upowszechnienie zatrudniania jednostek w oparciu o elastyczne formy zatrudnienia. Osoby należące do tej grupy, pozbawione są siedmiu podstawowych form zabezpieczeń związanych z pracą, do których zalicza się: zabezpieczenie rynku pracy (stosowane możliwości pracy zarobkowej), zabezpieczenie zatrudnienia (ochrona przed zwolnieniem), zabezpieczenie miejsca pracy (zdolność i możliwość utrzymania niszy w zatrudnieniu plus ograniczenia w obniżaniu wartości umiejętności), bezpieczeństwo pracy (ochrona przeciwko wypadkom w pracy), zabezpieczenie reprodukcji umiejętności (uzyskanie umiejętności poprzez naukę zawodu), zabezpiecze- 
nie dochodu (zapewnienie dochodu stałego), zabezpieczenie reprezentacji (kolektywny głos na rynku pracy). Zdaniem badacza owe rodzaje zabezpieczeń zatrudnienia stają się coraz rzadsze na rynku pracy, co w szczególności odnosi się do sytuacji osób młodych (Standing 2014). Brak stabilizacji zawodowej skutkuje opóźnianiem momentu przyjmowania zobowiązań charakterystycznych dla dorosłości, takich jak założenie rodziny czy kupno mieszkania, dlatego też coraz bardziej powszechne staje się zjawisko „gniazdowania" (Szlendak 2010), czyli pozostawania w domu rodzinnym po zakończeniu okresu dojrzewania i edukacji.

\section{Wyniki badań własnych*}

W kontekście poruszanej problematyki, warto odnieść się do wyników badań własnych, związanych z gotowością badanej grupy młodzieży do podjęcia zobowiązań dotyczących jej aktywności zawodowej. Jednym z istotnych zadań jednostki przypadających na okres adolescencji, staje się osiągnięcie przez nią dojrzałości do samodzielnego funkcjonowania w przestrzeni rynku pracy. Nabywanie kompetencji niezbędnych do partycypacji w „świecie zawodów" ma charakter procesualny, składający się z szeregu decyzji edukacyjno-zawodowych podmiotu. Dokonywanie rozpoznania deklaracji młodych ludzi odnośnie ich oceny, pozwala na wyciąganie znaczących wniosków związanych ze stopniem ich dojrzałości i świadomym podejmowaniem wyborów.

Istotnego znaczenia płaszczyzny rozwoju zawodowego dla obszaru autoidentyfikacyjnego respondentów dowodzą udzielane przez nich odpowie-

* Badania własne zostały przeprowadzone w maju i czerwcu 2015 r. Ich cel koncentrował się wokół rozpoznania i nakreślenia struktury orientacji zawodowych młodzieży uczęszczającej do szkół zawodowych, jednakże można w nich zidentyfikować informacje odnoszące się do gotowości respondentów odnośnie do przyjęcia przyszłych zobowiązań zawodowych. Wykorzystano w nich metodę sondażu diagnostycznego, technikę ankiety oraz narzędzie w postaci kwestionariusza ankiety. Populację badawczą stanowili uczniowie szkół zawodowych i techników, spośród których wyodrębniono określoną grupę respondentów. Szkoły wybrane do badań usytułowane były na terenie województwa wielkopolskiego i kujawsko-pomorskiego w miejscowościach: Poznań, Toruń (duże miasta powyżej 100 tys. mieszkańców), Leszno, Gniezno (miasta liczące od 51 do 99 tys. mieszkańców), Lipno, Wyrzysk (miasteczka do 50 tys. mieszkańców) oraz Gronowo (wieś w gminie Lubicz w powiecie toruńskim). Badani reprezentowali uczniów klas pierwszych, drugich i trzecich jedenastu szkół ponadgimnazjalnych o zróżnicowanym profilu kształcenia. Łącznie wzięło w nich udział 697 respondentów. Określono poziom istotności statystycznej o wartości p < 0,05, którą przyjmuje się w naukach społecznych. 
dzi na pytanie „Kim chciałbym / chciałabym być?”, w przypadku którego aż 60,0 \% z nich wskazywało tendencję dookreślania siebie przez pryzmat sfery życia zawodowego. Badani uczniowie dokonywali tego przez odwoływanie się do przyszłych ról zawodowych związanych zazwyczaj z aktualnym profilem kształcenia („chcę być fryzjerką”, „sprzedawcą”, „kosmetyczką”, „sekretarką”, „informatykiem”, „rolnikiem”, „kucharzem” itp.) lub poprzez zdefiniowanie oczekiwanych warunków pracy („chcę być kimś docenianym ze strony pracodawcy”, „pracownikiem wielkiej firmy”) albo jakości jej świadczenia (najczęściej przez dodanie przymiotnikowego kwantyfikatora do słowa pracownik lub nazwy zawodu, np. „chcę być dobrym pracownikiem”, „profesjonalnym elektrykiem”, „fachowcem w zawodzie”). Nieznaczna grupa respondentów przejawiała minimalistyczne oczekiwania w stosunku do przyszłości, wskazując, że może być każdym, byle nie bezrobotnym. Niniejsze zorientowanie w karierze pozostaje w ścisłym powiązaniu ze strategiami zachowania młodzieży wobec pracy wyróżnionymi przez Ewę Giermanowską. Badaczka wskazuje na istnienie dwóch sposobów działania odnoszących się do sfery życia zawodowego: nastawionych na „zrobienie kariery" (uzyskanie wysokiego wykształcenia ułatwiającego zdobycie prestiżowej pracy) oraz ukierunkowanych na "niepozostanie na bezrobociu" (ukierunkowanie na znalezienie jakiejkolwiek pracy przynoszącej gratyfikacje zarobkowe) (Giermanowska 2001, s. 229). Do grona pozostałych obszarów identyfikacji przyszłościowych badanych uczniów należą kategorie takie jak: zorientowanie na strefę sukcesu zawodowego (9,7\%), pasji / zainteresowań (9,7\%), tożsamości roli, czego dokonywali przede wszystkim poprzez przypisywanie różnorodnych kwantyfikatorów przymiotnikowych słowu „człowiek” (8,6\%), życia rodzinnego (4,5\%), pozostanie takim, jakim się jest (3,7\%), „stanie się kimś innym” (1,0\%), „przyszłość edukacyjna” $(0,7 \%)$, „stanie się nikim” ( $0,3 \%)$, „nie wiem” $(1,8 \%)$.

Należy zaznaczyć, iż identyfikacja młodzieży biorącej udział w sondażu diagnostycznym z obszarem życia zawodowego dostrzegalna jest także w przypadku jej „ja” teraźniejszego". Badani opisując swoją osobę, najczęściej odwoływali się do nazw o profilu indywidualistycznym, które stanowiły 38,0\% ogólnej liczby skojarzeń, następnie odnosili się do cech fizycznych $(23,7 \%)$ i sfery życia edukacyjno-zawodowego (11,2\%). W mniejszym zaś

* Było to pytanie otwarte, na które uczniowie mogli udzielić dowolnej odpowiedzi z jej uzasadnieniem.

** Rozpoznawanego za pomocą testu TST (Twenty Statements Test), polegającego na wskazaniu przez respondentów maksymalnie dwudziestu określeń dotyczących swojej osoby, zwracając uwagę na kolejność skojarzeń w odpowiedzi na pytanie: „Kim jestem?”. 
stopniu utożsamiali się ze swoimi atrybutami związanymi z określeniem pełnionej roli (10,2\%), sferą życia osobistego (9,6\%) oraz rodzinnego (7,3\%). Warto nadmienić, iż otrzymane wyniki badań ukazują istotne różnice obrazu własnego „ja” badanych dziewcząt i chłopców. Przedstawicielki płci żeńskiej w większym stopniu identyfikują się z płaszczyzną życia rodzinnego oraz wskazują na właściwości intrapersonalne, podczas gdy przedstawiciele płci męskiej dookreślają siebie poprzez cechy związane z rozwojem zawodowym.

Analizy uzyskanego materiału empirycznego dowodzą, że młodzież dookreśla siebie nie tylko poprzez wyszczególnienie cech o charakterze intra- i interpsychicznym, ale także w odniesieniu do interakcji ze światem społecznym. Co prawda, definiowane identyfikacje w znacznym stopniu dotyczą indywidualnych właściwości respondentów, jednakże nie pozostają oderwane od oceny otoczenia, w którym funkcjonują. Badani dążą do tego, by postrzegać ich jako osoby dojrzałe, odpowiedzialne, sumienne, by okazywać im szacunek, miłość, akceptację, zarówno w środowisku osobistym, jak i zawodowym. Owe prawidłowości świadczą o tym, że pomimo iż „osoba jest pojmowana jako aktywna jednostka, pragnąca racjonalnie, autonomicznie i w świecki sposób doświadczać odpowiedzialności za swój los" (Rose 1996, s. 320), nie funkcjonuje niezależnie od świata społecznego. Stworzenie tożsamości osobistej, rozumianej jako „subsystem samowiedzy, na który składają się cechy spostrzegane przez podmiot jako dla własnej osoby najbardziej charakterystyczne i zarazem najbardziej specyficzne, to jest najbardziej odróżniające własną osobę od innych ludzi” (Jarymowicz 2000, s. 125), wymaga współuczestnictwa pozostałych członków zbiorowości.

O ile w wyobrażeniu Ja realnego (odpowiedź na pytanie: „Kim jestem?”) badanej młodzieży dominują wskazania na „tożsamość ego” obejmującą jej osobiste atrybuty jednostkowe, o tyle skojarzenia odnoszące się do Ja idealnego (odpowiedź na pytanie: „Kim chciałbym / chciałabym być?”) ujawniają tendencję do samookreślania się przez pryzmat „tożsamości roli” definiowanej przede wszystkim poprzez nazwy zawodów, jakie już praktykuje lub chciałaby wykonywać w przyszłości. W tym miejscu, warto dopowiedzieć, że wyniki badań H. Liberskiej (Liberska 2004, s. 118-131) ujawniają wnioski, które stanowią istotną wartość dla analizowanego kontekstu prowadzonych eksploracji. Autorka ta uznała „wiek” za czynnik oddziałujący na czasowe rozmieszczenie oraz natężenie oczekiwań badanej grupy młodzieży dotyczących różnych płaszczyzn jej egzystencji, takich jak założenie rodziny, sukces życiowy czy też kariera zawodowa. Ponadto stwierdziła, że „wzrost koncentracji myślenia młodzieży o przyszłości w obszarze kariery zawodowej na- 
leży interpretować jako przejaw rozwoju realistycznej orientacji zawodowej zachodzącego w toku dorastania" (tamże, s. 130). Godzi się zatem przewidywać, że aspiracje respondentów związane z sukcesem zawodowym definiowanym poprzez pryzmat ról, takich jak zostanie prezydentem, królem, mistrzem, milionerem, będą stopniowo redukowane do planów, których spełnienie leży w zasięgu ich możliwości. Również wyniki badań R. Lepperta (Leppert 2010, s. 72-73) sygnalizują, że dynamika czasowa stanowi znaczny determinant przeobrażeń w strukturze autoidentyfikacji młodzieży. Badani przez niego uczniowie kreując wizję własnej przyszłości w większości odnosili się do kategorii zawodu. Na podstawie owych podobieństw implikacyjnych, wskazane jest stwierdzenie, że młodzi ludzie dookreślają siebie poprzez pryzmat aktualnych celów, aspiracji, których treść uwarunkuje etap rozwoju jednostki.

Dążąc do zidentyfikowania decyzji, które są oceniane przez młodzież w kategoriach życiowo doniosłych, poproszono badanych o ustosunkowanie się do pytania: „Która z Twoich dotychczasowych decyzji jest dla Ciebie najważniejsza?"*. Odpowiedzi respondentów zostały skategoryzowane w zależności od sfer życia, których dotyczyły. Dzięki temu zgromadzono wiedzę odnośnie do obszarów, w jakich lokują oni zdarzenia, które w ich opinii zasługują na miano „decyzji życiowo doniosłych”. Uzyskane wyniki badań ukazują, że temat namysłu nad przyszłością edukacyjno-zawodową nie jest obcy dla młodzieży realizującej naukę w szkołach ponadgimnazjalnych. Prym w tej kwestii wiodą jednak wybory związane $\mathrm{z}$ obszarem szkolnym (41,3\%). Bardzo często określano je w krótkim stwierdzeniu: „najważniejszy był dla mnie wybór szkoły" oraz niejednokrotnie doprecyzowywano przez podanie nazwy aktualnej placówki kształcenia. Z powodzeniem można więc zauważyć, że decyzje te odwołują się do kwestii mających miejsce w przeszłości oraz realizowanych w czasie teraźniejszym. W kontekście rozważań nad decyzjami życiowo doniosłymi, koncentracja badanych uczniów na aspektach edukacyjnych, nie powinna zaskakiwać, ponieważ stanowi charakterystyczny przedmiot refleksji dla osób będących w czasie edukacji oraz odnosi się do wydarzeń mających miejsce w niedalekiej przeszłości. Wyróżnikiem myślenia respondentów o decyzjach życiowo doniosłych, jest również znaczące poparcie dla obszaru zawodowego (16,0\%). Do grona tego rodzaju wyborów, zaklasyfikowano wypowiedzi młodzieży odnoszące się do przyszłych

* Inspiracją do konstrukcji pytania odnoszącego się do niniejszej kwestii, był Kwestionariusz Dokonywania Decyzji Życiowo Doniosłych autorstwa $\mathrm{Cz}$. Walesy, w wersji zmodyfikowanej przez L. Mac-Czarnik i E. Rydz. (Mac-Czarnik 2000) 
celów zawodowych, które uzależnione są od jej obecnych działań, a więc posiadają wyraźne nacechowanie futurystyczne. Wśród decyzji życiowo doniosłych, których znaczenia dla badanej młodzieży nie sposób pominąć, należy wymienić decyzje dotyczące jej kontaktów interpersonalnych (7,2\%), decyzje o charakterze intrapersonalnym $(6,3 \%)$ swoim zasięgiem obejmujące wypowiedzi respondentów, odnoszące się do ich osobistych potrzeb oraz wartości, związanych z ich życiem wewnętrznym lub też ciałem, przynoszące im zadowolenie, satysfakcję albo poczucie sukcesu, decyzje ukierunkowane na inwestycję we własny rozwój $(5,8 \%)$ związane $z$ jej wszelkimi działaniami zorientowanymi na zwiększanie zasobów własnej wiedzy tudzież kompetencji. Pozostali badani wskazywali decyzje dające się sklasyfikować jako: rodzinne $(5,2 \%)$ (wszelkie fakty obejmujące życie rodzinne, pozostanie $\mathrm{w}$ domu, wyprowadzenie się $\mathrm{z}$ domu rodzinnego lub też planowane przyszłe wydarzenia, o których zadecydowano wcześniej, np. założenie własnej rodziny), konsumpcyjne (3,0\%) lub odnoszące się do korzystania z prawa do wolności, uczestnictwa w wyborach rządowych), nazwane mianem pojawiającego się sformułowania: „każda decyzja jest dla mnie ważna” (0,5\%).

Wyniki badań Lucyny Mac-Czarnik (Tamże, s. 80-85) również dowodzą, że decyzje dotyczące edukacji i wyboru zawodu, stanowią najbardziej znaczący obszar związany z planowaniem życia oraz myśleniem o przyszłości dla młodzieży. Odpowiedzi badanej przez nią grupy dające się zakwalifikować jako edukacyjno-zawodowe wynosiły odsetek 37,8\% wszystkich typów decyzji. Kolejnymi istotnymi sferami wyborów adolescentów były: życie religijne (31,5\%), samodzielne organizowanie życia (17,7\%), relacje osobowe $(9,2 \%)$, doskonalenie siebie (3,8\%). Różnicujący z powyżej przedstawionymi danym jest fakt, że w grupie badanej młodzieży z zespołów szkół zawodowych w ogóle nie wystąpił typ decyzji należących do obszaru życia religijnego.

Donald E. Super zakładał, iż istotnym determinantem podjęcia aktywności zawodowej przez podmiot jest jego „dojrzałość do zawodu”, czyli zdolność do sprostania swoim aspiracjom oraz wymogom otoczenia w odniesieniu do wypełniania określonych ról i wynikających z nich powinności. Oznacza ona pewnego rodzaju umiejętność odnajdywania kompromisu pomiędzy indywidualnymi pragnieniami i oczekiwaniami środowiska w konfrontacji zarówno $\mathrm{z}$ wiekiem jednostki, jak i jej zdolnościami i umiejętnościami. Nie bez znaczenia dla jej kształtowania są takie elementy jak: akceptacja odpowiedzialności, umiejętność planowania i świadomość różnych aspektów życia zawodowego. Czynnikiem warunkującym powodzenie w sferze życia zawodowego jest także „dojrzałość do kariery zawodowej”, 
czyli samoświadomość własnego potencjału i zdolność do kierowania swoim rozwojem w powiązaniu $\mathrm{z}$ wiedzą na temat zawodów i rynku pracy. $\mathrm{Na}$ podstawie powyższych rozstrzygnięć, można wysnuć konkluzję, że „dojrzałość do zawodu" odnosi się do płaszczyzny zewnętrznej egzystencji jednostki i ma wymiar praktycznego działania w kontekście sfery społecznej, podczas gdy „dojrzałość do kariery zawodowej” wyznaczana jest przez stopień zaawansowania wewnętrznej motywacji człowieka w stosunku do sterowania własnym rozwojem (Super 1994).

Z kolei w rozważaniach Marka L. Savickasa doniosłe znaczenie ma niewątpliwie podkreślenie kompetencji „przystosowalności do kariery”, rozumianej jako „psychospołeczny konstrukt, który oznacza, że jednostka posiada zasoby i gotowość, aby radzić sobie $\mathrm{z}$ aktualnymi i nadchodzącymi zawodowymi zadaniami rozwojowymi, tranzycjami związanymi z pracą oraz osobistymi trudnymi sytuacjami. Przystosowalność pozwala jednostce ukształtować zasięg jej społecznego środowiska, ponieważ łączą się ze społeczeństwem i regulują własne zachowania zawodowe uwzględniając narzucone przez wspólnotę zadania rozwojowe i tranzycje jakich doświadczają w zawodowych rolach. Przystosowalność kariery działając jako strategia samoregulacji, umożliwia jednostkom skutecznie wprowadzać do ról zawodowych własne koncepcje, dzięki czemu mogą kreować własne życie zawodowe i konstruować własne kariery" (Minta 2012, s. 22). Pojęcie przystosowalności kariery można interpretować jako termin zastępujący określenie dojrzałości kariery D.E. Supera. Doskonale wpisuje się bowiem w specyfikę współczesnych czasów, w których podmiot odpowiedzialny za własną karierę, świadomy swoich zasobów i umiejętności, partycypuje w rzeczywistości społecznej kreując plan rozwoju zawodowego.

Przygotowanie młodych ludzi do realizacji zadań wynikających z przyjmowanej roli zawodowej można oszacować na podstawie pytań o ocenę trafności własnych wyborów związanych z karierą. Wyniki przeprowadzonych analiz dowodzą, iż ponad połowa badanej młodzieży (52\%) w przyszłości pragnęłaby zawodowo praktykować zajęcie, które jest zgodne z jej profilem kształcenia. W przypadku tych osób, można z dużym prawdopodobieństwem założyć, że dokonany przez nie wybór zawodu, był decyzją świadomą. Oznacza to, że uczeń ją podejmujący „zna wybierany zawód na tyle dokładnie, aby orientować się w wymaganiach stawianych przez ten zawód, w istotnych cechach tego zawodu wyróżniających go spośród innych zawodów [...] [oraz - dop. L.M.] wie, czy dysponuje podstawowymi warunkami psychofizycznymi umożliwiającymi prawidłowe wykonywanie wybranego zawodu, a także czy wybrany zawód interesuje go bardziej niż inne za- 
wody" (Rachalska 1993, s. 5). Istotną informacją pozwalającą zweryfikować trafność decyzji zawodowych podjętych przez badaną młodzież jest określenie przez nią stopnia przekonania o tym, że wybrane zajęcie, jakie zamierza praktykować w przyszłości, jest dla niej odpowiednie. Okazuje się, że znaczna grupa uczniów, stanowiąca odsetek 28,6\% ogółu respondentów, sympatyzuje ze stwierdzeniem, że zawód, w którym starają się aktualnie zdobyć kwalifikacje, będzie odpowiadał im całkowicie. Znaczące potwierdzenie owego przeświadczenia jest dostrzegane w korelacji statystycznej występującej pomiędzy daną właściwością a zmienną „zawód, jaki młodzież chciałaby wykonywać w przyszłości" $(\chi 2=133,027 ; d f=18 ; p \leq 0,001)^{*}$.

Elastyczność w kwestii własnych preferencji zawodowych wykazują respondenci, którzy w odpowiedzi na pytanie o przyszłość zawodową podali nazwę więcej niż jednego zajęcia, przy czym jedno z nich odpowiadało realizowanemu kierunkowi edukacji (14,5\%). Na trudnienie się profesją zbliżoną do tej, którą badani mają szansę poświadczyć kwalifikacyjnym dyplomem zawodowym, wskazuje 5,2\% adolescentów. W niniejszej grupie zostały umieszczone deklaracje pozwalające na przyporządkowanie do branży, w jakiej aktualnie kształci się nastolatek, jednak nie będące wiernym odzwierciedleniem zawodu wyuczonego. Nazwa fachu, za którym optowali badani, najczęściej wynikała $z$ awansu, jaki pragnęliby osiągnąć w przyszłości, jednak jego uzyskanie wymagałoby od nich podnoszenia kwalifikacji, np. osoby kształcące się w kierunku sprzedawca chciałyby zostać kierownikami sklepu, zaś technicy budownictwa - kierownikami budowy, lub też wyższego poziomu specjalizacji, np. technicy informatycy reflektują w kierunku pracy na stanowisku programisty. Należy także zauważyć, że liczną grupę stanowi młodzież, która nie dąży do praktykowania aktualnie kształconego zawodu w okresie swojej aktywności zawodowej na rynku pracy $(28,2 \%)$. Warto w tym miejscu odnotować, że wbrew temu, co można by przypuszczać, na chęć pracy w innym zawodzie wcale nie oddziałuje jego wybieranie pod wpływem spontanicznego impulsu $(\chi 2=17,357 ; d f=12 ; p=0,137)$ czy też nieumiejętność uzasadnienia swojej decyzji przez badaną młodzież $(\chi 2=$ $9,792 ; d f=12 ; p=0,634)$. Zależność ta dostrzegana jest w przypadku bariery kariery, jaką jest niezdecydowanie dotyczące tego, co respondenci chcieliby robić w przyszłości $(\chi 2=27,108 ; d f=3 ; p \leq 0,001)$. Zmienna ta dowodzi, że co trzecia badana osoba uznająca niniejszy czynnik za przeszkodę w rea-

* Do wykazania tej zależności pomiędzy zmiennymi zastosowano test chi-kwadrat, określono poziom istotności statystycznej o wartości $\mathrm{p} \leq 0,05$. 
lizacji ścieżki własnej przyszłości zawodowej, opowiada się za pragnieniem podjęcia pracy w innym obszarze niż wyuczony (34,5\%).

\section{Konkluzje}

Okres wchodzenia w dorosłość z powodzeniem można uznać za jeden z najbardziej newralgicznych etapów życia człowieka, którego przebieg ma istotne znaczenie dla jego dalszej biografii. Młodzi ludzie stoją przed zadaniem osiągnięcia niezależności od rodziców oraz przyjęcia odpowiedzialności za podejmowane decyzje. Młodzież z zespołów szkół zawodowych po uzyskaniu uprawnień do praktykowania wybranego zawodu zdobędzie szansę na aktywną partycypację w przestrzeni rynku pracy, a zatem sprostania jednemu z wymogów dorosłości. Znalezienie zatrudnienia to fundamentalny krok na drodze do samodzielnego życia, opuszczenia domu rodzinnego czy też założenia własnej rodziny.

Otrzymany materiał empiryczny ukazuje zróżnicowany obraz młodzieży. Dowodzi bowiem, iż u badanych adolescentów dominuje optymistyczna postawa wobec własnej kariery, o czym świadczy fakt, iż deklarują oni wiarę w słuszność dokonanych wyborów zawodowych. Należy jednak zauważyć, iż znacząca grupa respondentów wyraża chęć pracy w innym zawodzie oraz prezentuje elastyczne podejście do kwestii swojego zatrudnienia. Sytuacja ta może być uwarunkowana przez różne czynniki, takie jak dynamizm obecnego świata, czy też posiadanie niewystarczającej wiedzy na swój temat przez młodzież, co wynika z dążenia przez nią do wywiązania się z kolejnego zadania rozwojowego, jakim jest kształtowanie tożsamości. Niemniej sfera rozwoju zawodowego okazuje się dla nich istotna, co potwierdzają dane dotyczące aspektu autoidentyfikacyjnego i dookreślania siebie przez pryzmat roli społecznej. Eksperymentowanie na ścieżce własnej kariery oraz otwartość na różnorodne doświadczenia to domena nie tylko „wschodzącej dorosłości", ale także współczesnego świata, obligującego do życia w warunkach niepewności.

\section{Bibliografia}

Arnett J.J. (2000), Emerging adulthood. A theory of development from the late teens through the twenties, „American Psychologist”, 55(5), s. 469-480. 
Arnett J.J. (2004), Emerging adulthood: The Winding Road from the Late Teens Through the Twenties, Oxford University Press, New York.

Arnett J.J., Tanner J.L. (2005), Emerging Adults in America: Coming of Age in the 21st Century, American Psychological Association Press, Washington.

Balcerowicz-Szkutnik M., Wąsowicz J. (2017), Pokolenie NEETs na rynku pracy - aktualne problemy, „Studia Ekonomiczne. Zeszyty Naukowe Uniwersytetu Ekonomicznego w Katowicach", 312, s. 7-17.

Bańka A. (2006), Psychologiczne doradztwo karier, Stowarzyszenie Psychologia i Architektura, Poznań.

Bauman Z. (2007), Płynne życie, Wydawnictwo Literackie, Kraków.

Bowman D., Borlagdan J., Bond S. (2015), Making sense of youth transitions from education to work, Brotherhood of St Laurence, Fritzroy.

Cross G. (2008), Men to boys. The making of modern immaturity, Columbia University Press, New York.

Drabik-Podgórna V. (2010), Tranzycja jako nowa kategoria biograficzna we współczesnym poradnictwie zawodowym, „Edukacja Dorosłych”, 1, s. 91-104.

Drwal R. (1993), Percepcja ważności i realizacji zadań rozwojowych przez dorastajacych, [w:] Smoleńska Z. (red.), Badania nad rozwojem w okresie dorastania, Instytut Psychologii Polskiej Akademii Nauk, Warszawa, s. 15-47.

Dubas E. (2009), Etapy dorosłości i proces kształcenia, [w:] Fabiś A., Cyboran B. (red.), Dorosły w procesie kształcenia, BED, Bielsko-Biała, s. 115-132.

Epstein, J. (2003), The perpetual adolescent, „Weekly Standard”, 15 March.

Erikson E.H. (2004), Tożsamość a cykl życia, Zysk i S-ka, Poznań.

Gerrig R. J., Zimbardo P.G. (2006), Psychologia i życie, PWN, Warszawa.

Giemanowska E. (2001), Między karierq a bezrobociem, [w:] Fatyga B., Tyszkiewicz A. (red.), Normalność i normalka. Próba zastosowania pojęcia normalności do badań współczesnej młodzież, Instytut Stosowanych Nauk Społecznych UW, Warszawa 2001, s. 214-238.

Gilleard Ch., Higgs P. (2005). Contexts of Ageing: Class, Cohort and Community, Polity Press, Cambridge.

Giuchard J. (2007), Transition, [w:] Guichard J., Huteau M. (red.), Orientation et insertion professionnelle. 75 concepts cles, Dunod, Paris 2007

Havighurst R.J. (1981), Developmental Tasks and Education, Longman, New York and London.

Hendry L., Kloep M. (2010), How universal is emerging adulthood. An empirical example, „Journal of Youth Studies”, 13(2), s. 169-179.

Inhelder B., Piaget J. (1970), Od logiki dziecka do logiki młodzieży: rozprawa o ksztattowaniu się formalnych struktur operacyjnych, PWN, Warszawa.

Jarymowicz M. (2000), Psychologia tożsamości [w:] Strelau J. (red.), Psychologia. Podręcznik akademicki, tom III, Gdańskie Wydawnictwo Psychologiczne, Gdańsk, s. 107-125.

Leppert R. (2010), Młodzież - świat przeżywany i tożsamość, „Impuls”, Kraków. 
Liberska H. (2004), Perspektywy temporalne młodzieży. Wybrane uwarunkowania, Wydawnictwo Naukowe UAM, Poznań.

Liberska H. (2007), Wspótczesny obraz moratorium [w:] Harwas-Napierała B., Liberska H. (red.), Tożsamość a wspótczesność, Wydawnictwo Naukowe UAM, Poznań, s. 25-52.

Lipska A., Zagrórska W. (2011), „Stajq̨ca się dorosłośc” w ujęciu Jeffreya J. Arnetta jako rozbudowana faza liminalna rytuału przejścia, „Psychologia Rozwojowa”, 16(1), s. 9-21.

Liwiński J., Socha M. W., Sztanderska U. (2000), Wyksztatcenie a rynek pracy, [w:] Ekonomiczne i społeczne efekty edukacji, Instytut Współczesnych Problemów Cywilizacji, Warszawa, s. 27-85.

Mac-Czarnik L. (2000), Procesy poznawcze w planowaniu własnego życia u młodzieży. Badania rozwojowe osób w wieku od 12 do 25 lat, Wydawnictwo Wyższej Szkoły Pedagogicznej, Rzeszów.

Melosik Z., Szkudlarek T. (2010), Kultura, tożsamość i edukacja. Migotanie znaczeń, Oficyna Wydawnicza Impuls, Kraków.

Minta J. (2012), Od aktora do autora. Wspieranie młodzieży w wspieraniu własnej kariery, Krajowy Ośrodek Wspierania Edukacji Zawodowej i Ustawicznej, Warszawa.

Olejniczuk-Merta A. (2012), Kult młodości-moda czy długofalowa zmiana stylu życia, „Marketing i Rynek”, 8, s. 2-8.

Osppe J.M. (2016), Oblicze fenomenu kidults, „Tarnowskie Studia Teologiczne”, 35(2), s. 41-50.

Pilch T. (2003), Encyklopedia pedagogiczna XXI wieku, „Żak”, Warszawa.

Piróg D. (2013), Wybrane determinanty tranzycji absolwentów studiów wyższych na rynek pracy, „Studia Ekonomiczne”, 160, s. 131-138.

Rachalska W. (1993), Wprowadzenie [w:] Rachalska W. (red.), Model orientacji zawodowej w wyższej uczelni (na przykładzie wyższych szkół pedagogicznych), Wydawnictwo WSP, Częstochowa.

Reykowski J. (1986), Motywacja, postawy prospołeczne a osobowość, Państwowe Wydawnictwo Naukowe, Warszawa.

Rosalska M., Wawrzonek A. (2012), Między szkołq a rynkiem pracy. Doradztwo zawodowe w szkołach zawodowych, Difin, Warszawa.

Rose N. (1996), Authority and the genealogy of subjectivity, [w:] Helas P., Lash S., Morris P. (red.), Detraditionalization. Critical reflections on authority and identity, Cambridge.

Standing G. (2014), Prekariat. Nowa niebezpieczna klasa, PWN, Warszawa.

Super D.E. (1994), A Life Span, Life Space. Perspective on Convergence, [w:] Savickas M.L., Lent R.W. (red.), Convergence in Career Development Theories, CPP Books, California, s. 63-74.

Szaban J.M. (2013), Rynek pracy w Polsce i w Unii Europejskiej, Difin, Warszawa.

Szlendak, T. (2010), Socjologia rodziny. ewolucja, historia, zróżnicowanie, PWN, Warszawa. 
Tierney J. (2004), In a word; adultescent, „New York Times”, 26 December.

Tilbury C., Buys N., Creed P. (2009), Perspectives of Young People in Care About their School-to-Work Transition, „Australian Social Work”, 62(4), s. 476-490.

Trempała J. (2006), Deregulacja cyklu życia w planach życiowych młodzieży, „Polskie Forum Psychologiczne", 1, s. 108-120.

Turska E. (2014), Kapitał kariery ludzi młodych. Uwarunkowania i konsekwencje, Wydawnictwo Uniwersytetu Śląskiego, Katowice.

Varenhorst B. (1981), The adolescent society, [w:] Adolescent Peer Pressure. Theory, Correlates and Program Implications for Drug Abuse Prevention, Rockville, s. $1-20$. 